\title{
Evaluating of soil sulphur forms changes in long-term field experiments of Látókép
}

\author{
Evelin Kármen Juhász - Andrea Balláné Kovács \\ University of Debrecen, Faculty of Agricultural and Food Sciences and Environmental Management, Institute of Agricultural Chemistry and \\ Soil Science, Debrecen \\ evelinjuhasz570@gmail.com
}

\begin{abstract}
SUMMARY
The aim of this work was to evaluate the changes of different sulphur forms (soluble, adsorbed) in chernozem soil in a long-term field experiment supplied with increasing doses of NPK fertilizers for a long time. In addition, other objective of this study included the examination of the applicability of recommended extractants of the different sulphate fraction in Hungarian soils. A long-term field experiment was established at the Research Station of Látókép of the University of Debrecen in 1984. In addition to control, two levels of NPK fertilizer doses have been used with irrigated and non-irrigated variants. Winter wheat and corn were cropped in a crop rotation on plots. Soil samples were collected in three different development stages of winter wheat, at the stage of stem elongation (April), flowering (May) and ripening (June of 2018) from the topsoil $(0-20 \mathrm{~cm})$ of experiment plots. Water-soluble inorganic sulphate was extracted with $0.01 M \mathrm{CaCl}_{2}$ solutions. The soluble plus adsorbed sulphate was extracted with $0.016 \mathrm{M} \mathrm{KH}_{2} \mathrm{PO}_{4}$ solution. Sulphate was measured by

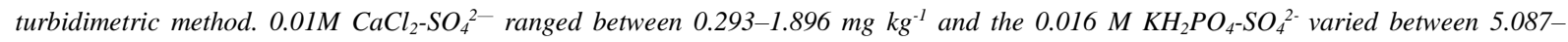
$10.261 \mathrm{mg} \mathrm{kg}^{-1}$. The values of $\mathrm{KH}_{2} \mathrm{PO}_{4} \mathrm{SO}_{4}{ }^{2-}$ was higher than that of $\mathrm{CaCl}_{2}-\mathrm{SO}_{4}{ }^{2-}$, because $\mathrm{KH}_{2} \mathrm{PO}_{4}$ extracted the adsorbed and soluble fractions of sulphate, while $\mathrm{CaCl}_{2}$ extracted the soluble sulphate fraction. The amount of absorbed sulphate was calculated by the differences of $\mathrm{KH}_{2} \mathrm{PO}_{4}-\mathrm{SO}_{4}$ and $\mathrm{CaCl}_{2}-\mathrm{SO}_{4}$. The $\mathrm{KH}_{2} \mathrm{PO}_{4}$ characterizes mainly the adsorbed sulphate fraction much more than the water-soluble fraction. $\mathrm{KCl}$ is the most widely used extractant for the determination of plant available sulphate content of soil in Hungary; therefore, KCl-

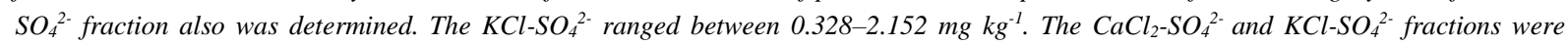
compared and based on Pearson's linear correlation, moderate correlation was established ( $r=0.511)$ between them. In all three extractant $\left(0.01 \mathrm{M} \mathrm{CaCl}_{2}, 1 \mathrm{M} \mathrm{KCl}, 0.016 \mathrm{M} \mathrm{KH}_{2} \mathrm{PO}_{4}\right)$ higher sulphate fractions were measured in the fertilized plots where superphosphate had been supplied for ages until 2010. The arylsulphatase activity of soil also was determined and ranged between 9.284 and $26.860 \mu \mathrm{g}$-nitrophenol $g^{-1} h^{-1}$. The lowest value was observed in the treatment with highest NPK2 dose, both in irrigated and non-irrigated areas.
\end{abstract}

Keywords: sulphur fractions, fertilization, long-term field experiment

\section{INTRODUCTION}

Bioavailable sulphur deficiency in soils is becoming an actual problem in many sites (Eriksen, 2005; Scherer, 2009). The increased occurrence of sulphur deficiency is due to reduced concentrations of primary air pollutants, the use of concentrated-NPK low-S fertilizers, the declining use of farmyard manure and $\mathrm{S}$ containing fungicides and pesticides (Scherer, 2001), at a time when yields have been increasing.

Sulphur is present in soils in the form of both inorganic and organic compounds. In general, inorganic sulphur species are fractionated into watersoluble sulphate, adsorbed sulphate, dilute-HCl soluble sulphur and volatile sulphur, pyritic sulphur (Johnson et al., 1981). Organic sulphur can be divided into two distinct fractions: carbon-bonded sulphur and ester sulphur (Pirela and Tabatabai, 1988). The most important $\mathrm{S}$ source for plants is sulphate $\left(\mathrm{SO}_{4}{ }^{2-}\right)$ in the soil solution.

Arylsulphatases are enzymes that catalyse the hydrolysis of aromatic sulphate ester to phenols and inorganic sulphate. Sulphate esters represent a large fraction of the total $S$ of soil and therefore, arylsulphatases may be important for mobilisation of inorganic sulphate for plant nutrition (Fitzgerald, 1976).

From the mentioned reasons it is clear that sulphur is becoming a limiting factor for the production quality (Eriksen et al., 2004). Therefore, it is necessary to pay attention to get more information about different sulphur fractions in soil.

The aim of this study was to evaluate the changes of different sulphur forms (soluble, adsorbed) in chernozem soil in a long-term field experiment supplied with increasing doses of NPK fertilizers for a long time, considering that $\mathrm{S}$ containing $\mathrm{P}$ fertilizer (as superphosphate) was not used since 2010. Furthermore, other objective of this study was to examine and compare of different extractants that are recommended for measuring of the different sulphate fraction.

\section{MATERIALS AND METHODS}

A long-term field experiment was established at the Research Station of Látókép of the University of Debrecen in 1984, by Ruzsányi László. It is located 15 $\mathrm{km}$ from Debrecen in Hungary. The soil is a calcareous chernozem with 2.8-3.0\% humus content. The depth of the humus layer is $70-90 \mathrm{~cm}$. Main parameters of the experimental soil are $\mathrm{pH}\left(\mathrm{CaCl}_{2}\right)$ $=7.2 ; \mathrm{Hu} \%=2.8 ; \mathrm{K}_{\mathrm{A}}=37.5 ; \mathrm{AL}-\mathrm{P}_{2} \mathrm{O}_{5}=394.1 \mathrm{mg} \mathrm{kg}^{-1}$; $\mathrm{AL}-\mathrm{K}_{2} \mathrm{O}=190.8 \mathrm{mg} \mathrm{kg}^{-1} ; \mathrm{AL}-\mathrm{Ca}=5130 \mathrm{mg} \mathrm{kg}^{-1} ; \mathrm{AL}-$ $\mathrm{Mg}=403.0 \mathrm{mg} \mathrm{kg}^{-1}$.

The experiment consists of treatments with increasing NPK doses with irrigated and non-irrigated variants (Table 1). 
Rates of mineral fertilizers applied at the experiment (Látókép)

\begin{tabular}{ccccc}
\hline \multicolumn{2}{c}{ Treatments } & $\mathrm{N}\left(\mathrm{kg} \mathrm{ha}^{-1}\right)$ & $\mathrm{P}_{2} \mathrm{O}_{5}\left(\mathrm{~kg} \mathrm{ha}^{-1}\right)$ & $\mathrm{K}_{2} \mathrm{O}\left(\mathrm{kg} \mathrm{ha}^{-1}\right)$ \\
\hline \multirow{2}{*}{ irrigated } & control & 0 & 0 & 0 \\
& NPK1 & 100 & 70 & 160 \\
\hline \multirow{2}{*}{ non-irrigated } & NPK2 & 200 & 0 & 0 \\
& control & 0 & 70 & 80 \\
& NPK1 & 100 & 140 & 160 \\
\hline
\end{tabular}

Each treatment consists of $46 \mathrm{~m}^{2}$ plots, arranged in a randomized block design with four replications. Besides control two levels of NPK fertilizer doses have been used. Winter wheat and corn were cropped in a crop rotation on plots.

At the first part of the experiment, between 1984 and 2010, the $\mathrm{N}, \mathrm{P} \mathrm{K}$ were supplied as $\mathrm{NH}_{4} \mathrm{NO}_{3}$, superphosphate and $\mathrm{KCl}$, respectively. The superphosphate is a sulphur containing fertilizer, with $10.9 \%$ sulphur content. From 2010 the superphosphate was replaced by monoammonium dihydrogen phosphate (MAP) and sulphur was not supplied any more in this area. Solid N, P and K fertilizers were mixed into the soil before sowing.

In the soil sampling year (2018) there was $25 \mathrm{~mm}$ rain in April, $55 \mathrm{~mm}$ in May and $55 \mathrm{~mm}$ in June, and there was no need to irrigate in the experimental area. However, irrigation of the previous years make it possible to distinguish irrigated and non-irrigated areas.

Soil samples were collected in three different development stages of winter wheat, at the stage of stem elongation (April), flowering (May) and ripening (June of 2018) from the topsoil $0-20 \mathrm{~cm}$ of experimental plots. Soil samples were air dried, ground and passed through a $2 \mathrm{~mm}$ sieve.

Water-soluble inorganic sulphate was extracted with $1 \mathrm{M} \mathrm{KCl}$ and $0.01 \mathrm{M} \mathrm{CaCl}{ }_{2}$ solution. The soluble plus adsorbed sulphate was extracted with $0.016 \mathrm{M}$ $\mathrm{KH}_{2} \mathrm{PO}_{4}$ solution. $10 \mathrm{~g}$ soil was shaken with $25 \mathrm{ml}$ extractants. Extracts were filtered and sulphate was measured by turbidimetric method (Zhao and McGrath, 1994). This method based on the forming of $\mathrm{BaSO}_{4}$ precipitate in a slightly acid medium when excess $\mathrm{BaCl}_{2} * 2 \mathrm{H}_{2} \mathrm{O}$ is added to a solution containing sulphate-S. For the determination of absorbed soil sulphate $0.01 \mathrm{M} \mathrm{CaCl} \mathrm{Cl}_{2}$ soluble sulphate also was determined and the absorbed sulphate was calculated with the difference of $\mathrm{KH}_{2} \mathrm{PO}_{4}-\mathrm{SO}_{4}$ and $\mathrm{CaCl}_{2}-\mathrm{SO}_{4}$. The soil $\mathrm{pH}$ was determined in a 1:2.5 soil to $1 \mathrm{M} \mathrm{KCl}$ and distilled water.

The activity of arylsulphatase was determined using p-nitrophenol sulphate as a substrate (Tabatabai and Bremner, 1970b). This method is based on conversation of $p$-nitrophenyl sulphate to $\mathrm{p}$ nitrophenol and sulphate, which can be quantified by turbidimetrically.

For statistical analysis of experimental results IBM SPSS Statistics 22 and Microsoft Excel 2016 programs were used. The mean values of each treatment group were subjected to comparisons analysis using the One-Way ANOVA (significance level of $p<0.05$ ) with post hoc comparisons using Tukey test and Pearson's linear correlation was used to determine the relationship between extractants. The measured values were analysed separately in three different development stages.

\section{RESULTS AND DISCUSSION}

\section{$\mathrm{CaCl}_{2}$ soluble $\mathrm{SO}_{4}{ }^{2-}$ content of soil}

The Figure 1 shows the result of $0.01 \mathrm{M} \mathrm{CaCl}$ soluble $\mathrm{SO}_{4}{ }^{2-}$-content of soil. This extractant is a weak salt solution and it solves the water soluble inorganic fraction (Hu et al., 2005).

At the stage of stem elongation of wheat the $\mathrm{CaCl}_{2}$ soluble $\mathrm{SO}_{4}{ }^{2-}$-content of soil ranged between $0.419-$ $1.047 \mathrm{mg} \mathrm{kg}^{-1}$. The sulphate-content of irrigated and non-irrigated area were almost the same. At this stage higher sulphate was measured in fertilized plots and the highest fertilizer dose (NPK2) caused the most increased $\mathrm{CaCl}_{2}$ soluble sulphate in soil. It can be also establish, that there was no big difference between the control and NPK1 treatment at this development stage.

From April to May there was an increment in soluble sulphate of soil. At the stage of flowering the sulphate values varied between $0.838-1.896 \mathrm{mg} \mathrm{kg}^{-1}$ The increment of sulphate in time can be explain by the fact, that comparing to May there was more than $50 \mathrm{~mm}$ of rain average (Net1) in April and the solubility of sulphate changed. At this time the lowest value was observed in control treatments, and the highest value was detected in NPK2 treatments in the irrigated area and in NPK1 treatment in the nonirrigated area. The sulphate-content of non-irrigated area was a little bit higher than that of irrigated area. In this case, the increased fertilizer doses still enhanced the sulphate content a little bit compared to control.

From May to June, the sulphate content tended to decrease in the soil, which might be due to the more intensive nutrient uptake of plant after flowering. At the stage of ripening (measured in June), the sulphate content in fertilized plots was lower mostly in the irrigated area that can be explained by the fact, that higher yield probably resulted in higher sulphur uptake and lower sulphate-content of soil compared to the control. 
Figure 1: Change of $0.01 \mathrm{M} \mathrm{CaCl}{ }_{2}$ soluble $\mathrm{SO}_{4}{ }^{2-}$ of soil at different development stage of wheat

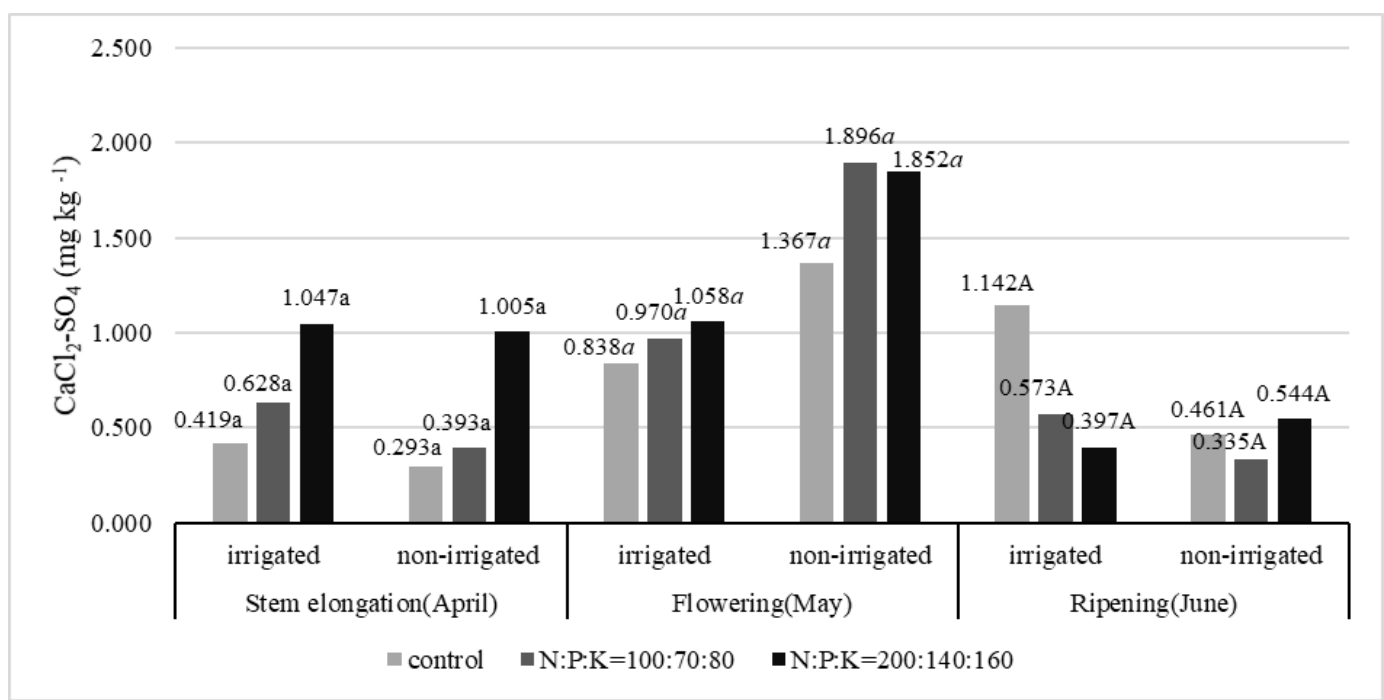

Note: data marked with the same letter is not significantly different at the significant level of $\mathrm{p}<0.05$

\section{$\mathrm{KH}_{2} \mathrm{PO}_{4}$ soluble $\mathrm{SO}_{4}{ }^{2-}$-content of soil}

Figure 2 shows the result of $\mathrm{KH}_{2} \mathrm{PO}_{4}$ soluble $\mathrm{SO}_{4}{ }^{2-}$ values. Based on our results, the values of $\mathrm{KH}_{2} \mathrm{PO}_{4-}$ $\mathrm{SO}_{4}{ }^{2-}$ were higher than that of $0.01 \mathrm{M} \mathrm{CaCl}{ }_{2}-\mathrm{SO}_{4}{ }^{2-}$, because $\mathrm{KH}_{2} \mathrm{PO}_{4}$ may extracts not only the soluble $\mathrm{SO}_{4}{ }^{2-}$ but adsorbed fraction as well, while $\mathrm{CaCl}_{2}$ extract soluble sulphate fraction of soil.

The $\mathrm{KH}_{2} \mathrm{PO}_{4}-\mathrm{SO}_{4}{ }^{2-}$ values was higher than values of $\mathrm{CaCl}_{2}-\mathrm{SO}_{4}^{2-}$ and ranged between 5.087-10.261 $\mathrm{mg} \mathrm{kg}{ }^{-1}$. A slight increment in the soil's sulphate content was observed in time, which was probably caused by the optimal condition for mineralization of the organic sulphur sources.

At the stage of stem elongation the sulphate-values varied between $5.087-6.948 \mathrm{mg} \mathrm{kg}^{-1}$. In this time, the sulphate-content of irrigated area was a little bit higher than that of non-irrigated area. There was no high differences between the control and fertilized treatments, only the highest fertilizer dose caused a little increased sulphate value in the irrigated area. However, in the non-irrigated areas, the treatments with increasing fertilizer doses resulted in decreased sulphate-values.

Figure 2: Change of $0.016 \mathrm{M} \mathrm{KH} \mathrm{H}_{2} \mathrm{PO}_{4}$ soluble $\mathrm{SO}_{4}{ }^{2-}$ of soil at different development stage of wheat

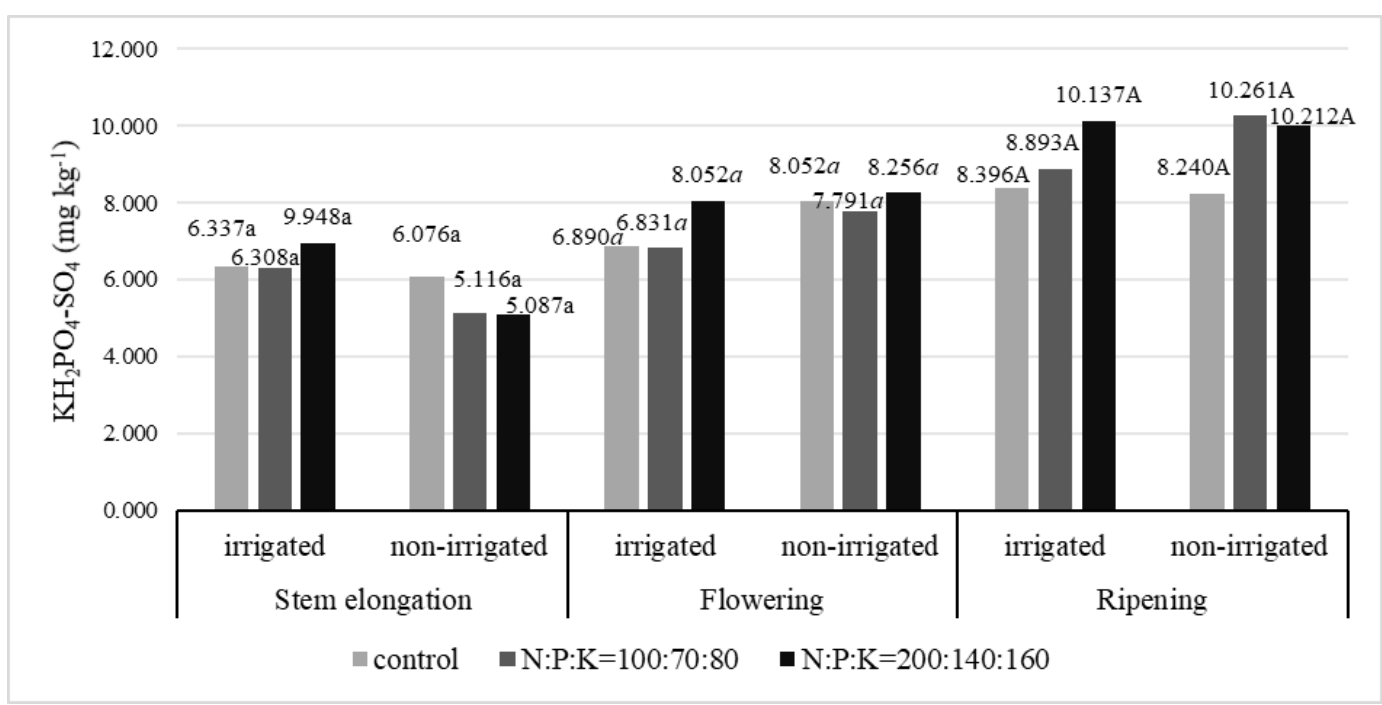

Note: data marked with the same letter is not significantly different at the significant level of $\mathrm{p}<0.05$

At the stage of flowering, measured in May, the sulphate-content ranged between 6.890-8.256 $\mathrm{mg} \mathrm{kg}^{-1}$. The values of the non-irrigated area was a little bit higher, than the results of irrigated area. In 
this time, the value of NPK1 treatment did not differ from value of control, but the NPK2 treatment (the highest fertilizer dose) resulted a little bit higher sulphate content of soil.

The $\mathrm{KH}_{2} \mathrm{PO}_{4}$ soluble $\mathrm{SO}_{4}{ }^{2-}$ measured at the ripening stage ranged between $8.240-10.261 \mathrm{mg} \mathrm{kg}^{-1}$. The lowest sulphate-content was measured in control treatments. The effect of increasing fertilizer doses clearly prevailed compared to the control treatment, because this treatments resulted higher sulphatecontent both in the irrigated and the non-irrigated area.

\section{The calculated adsorbed sulphate fraction of soil}

The adsorbed sulphate was calculated with the difference of values of $\mathrm{KH}_{2} \mathrm{PO}_{4}-\mathrm{SO}_{4}$ and values of $\mathrm{CaCl}_{2}-\mathrm{SO}_{4}{ }^{-2}$. The results of adsorbed sulphate content of soil is summarised in Table 2 .

The adsorbed sulphate values of chernozem soil ranged between 4.333 and $9.468 \mathrm{mg} \mathrm{kg}^{-1}$. Kulhánek et al. (2016) estimated similar values (3.80-10.6 $\mathrm{mg} \mathrm{kg}^{-1}$ ) on chernozem soil in a long term-field experiments. The changes of adsorbed sulphate depending on different treatments showed almost the same tendencies as the changes of values of $0.016 \mathrm{M}$ $\mathrm{KH}_{2} \mathrm{PO}_{4}$ soluble $\mathrm{SO}_{4}$. In this case of adsorbed sulphate a slightly increment was observed in time.

By the effect of growing rate of soil fertilizer the rate of adsorbed sulphate increased. According to Förster et al. (2012), $\mathrm{SO}_{4}{ }^{2-}$ - adsorption is strongly $\mathrm{pH}$ dependent and increases with decreasing $\mathrm{pH}$. In the long term fertilization experiment the $\mathrm{pH}$ decreased with increasing fertilizer doses. Highest $\mathrm{pH}_{(\mathrm{KCl})}$-values were measured in control treatments $\left(\mathrm{pH}_{(\mathrm{KCl})}=4.97-\right.$ 5.51) and lowest ones were observed in the NPK2 treatments $\left(\mathrm{pH}_{(\mathrm{KCl})}=4.42-4.80\right)$. This phenomenon can be observed in our results as well.

Based on Pearson's correlation analyzis high correlation was observed between values of adsorbed sulphate and $\mathrm{KH}_{2} \mathrm{PO}_{4}$ soluble sulphate $(\mathrm{r}=0.949)$. Summarizing this results, it can be concluded that the $\mathrm{KH}_{2} \mathrm{PO}_{4}$ extract better characterizes the adsorbed sulphate fraction than the water-soluble fraction.

The adsorbed sulphate fraction of soil at different development stage

\begin{tabular}{|c|c|c|c|c|c|c|}
\hline \multirow[b]{2}{*}{ Treatment } & \multicolumn{2}{|c|}{ Stem elongation } & \multicolumn{2}{|c|}{ Flowering } & \multicolumn{2}{|c|}{ Ripening } \\
\hline & Irrigated & Non-irrigated & Irrigated & Non-irrigated & Irrigated & $\begin{array}{c}\text { Non- } \\
\text { irrigated }\end{array}$ \\
\hline control & 5.709 & 5.531 & 6.052 & 6.685 & 7.999 & 7.779 \\
\hline $\mathrm{N}: \mathrm{P}: \mathrm{K}=100: 70: 80$ & 6.057 & 4.321 & 5.861 & 5.895 & 8.320 & 9.926 \\
\hline $\mathrm{N}: \mathrm{P}: \mathrm{K}=200: 140: 160$ & 6.236 & 4.333 & 6.994 & 6.404 & 8.517 & 9.468 \\
\hline
\end{tabular}

\section{KCl soluble $\mathrm{SO}_{4}{ }^{2-}$-content of soil}

Potassium-chloride is the most widely used extractant for the determination of plant available sulphate content of soil in Hungary, therefore this extractant was also investigated and the results of $\mathrm{KCl}-\mathrm{SO}_{4}{ }^{2-}$ were compared to the result of $0.01 \mathrm{M}$ $\mathrm{CaCl}_{2}-\mathrm{SO}_{4}{ }^{2-}$.
The $1 \mathrm{M} \mathrm{KCl}$ soluble $\mathrm{SO}_{4}{ }^{2-}$ values are summarized in Figure 3. $\mathrm{Hu}$ et al. (2005) stated that the $\mathrm{KCl}$ soluble $\mathrm{SO}_{4}{ }^{2-}$ represents the water-soluble inorganic sulphate fraction of soil.

Figure 3: $1 \mathrm{M} \mathrm{KCl} \mathrm{soluble} \mathrm{SO}_{4}{ }^{2-}$ of soil at different development stage of wheat

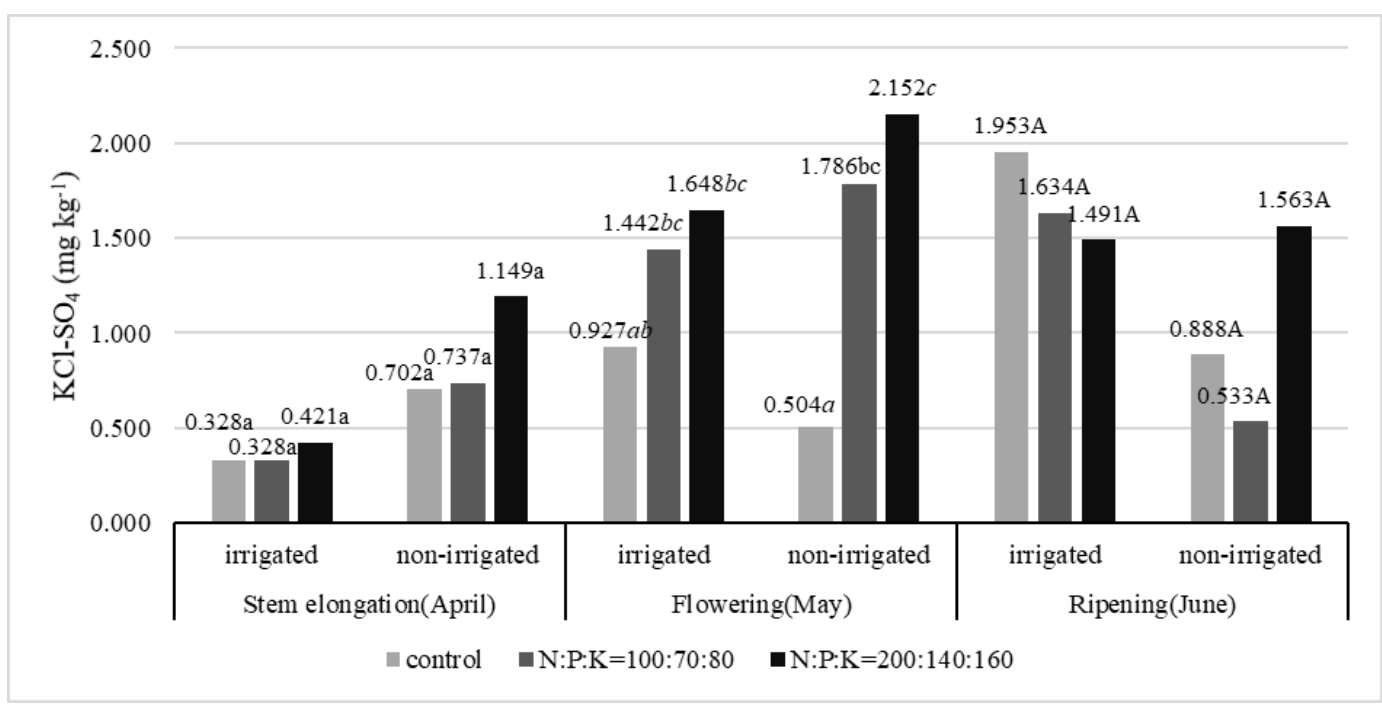

Note: data marked with the same letter is not significantly different at the significant level of $\mathrm{p}<0.05$ 
The changes of $\mathrm{KCl}$ soluble sulphate values showed similar tendency as the results of $0.01 \mathrm{M} \mathrm{CaCl}_{2}$ soluble $\mathrm{SO}_{4}$. The values of $\mathrm{KCl}-\mathrm{SO}_{4}{ }^{2-}$ tended to increase in time in irrigated plots, but a little drop was appeared after flowering stage in non-irrigated plots. In the most cases, the effect of increasing fertilizer doses appeared in the increased sulphate content of soil, although this increase was not statistically proven. At the stage of ripening the tendency of change was the same as the results of $0.01 \mathrm{M} \mathrm{CaCl}_{2}$ $\mathrm{SO}_{4}{ }^{2-}$ that is sulphate concentration slightly decreased with increased fertilizer doses.

Based on Pearson's correlation analyzis moderate correlation was observed between values of $1 \mathrm{M} \mathrm{KCl}$ soluble sulphate and the $0.01 \mathrm{M} \mathrm{CaCl}_{2}$ soluble sulphate $(\mathrm{r}=0.511)$.
The arylsulphatase activity at the stage of ripening

The relative proportions of inorganic and organic $S$ forms in soils vary widely. However, the organic $S$ compounds are dominant and a big proportion of the organic $\mathrm{S}$ is present as ester sulphates. Although ester sulphates are considered to be the most labile form of soil organic $\mathrm{S}$, they are unavailable to plants and must be hydrolysed to inorganic $\mathrm{SO}_{4}{ }^{2-}$ before plant uptake. In this process arylsulfatase is involved by cleaving the O-S bond and is believed to make a major contribution to the mineralization of ester sulphate in soils (Tabatabai, 1994).

The arylsulphatase activity of soil was measured in June and the results in different treatments are summarised in Table 3.

Arylsulphatase activity of chernozem soil (Látókép) in June

\begin{tabular}{|c|c|c|c|c|}
\hline \multirow[b]{2}{*}{ Treatments } & \multicolumn{2}{|c|}{$\begin{array}{l}\text { Arylsulphatase activity } \\
\left(\mu \mathrm{g} \text { p-nitrophenol } \mathrm{g}^{-1} \mathrm{~h}^{-1}\right)\end{array}$} & \multicolumn{2}{|c|}{$\mathrm{KH}_{2} \mathrm{PO}_{4}-\mathrm{SO}_{4}\left(\mathrm{mg} \mathrm{kg}^{-1}\right)$} \\
\hline & Irrigated & Non-irrigated & Irrigated & Non-irrigated \\
\hline control & 23.031 & 24.433 & 8.396 & 8.240 \\
\hline NPK1 & 26.860 & 22.420 & 8.893 & 10.261 \\
\hline NPK2 & 9.284 & 16.713 & 10.137 & 10.012 \\
\hline
\end{tabular}

The arylsulphatase activity of soil ranged between 9.284 and $26.860 \mu \mathrm{g}$ p-nitrophenol $\mathrm{g}^{-1} \mathrm{~h}^{-1}$. The lowest value was observed in NPK2 treatment, both in irrigated and non-irrigated areas. In general, it can be stated, that the higher sulphate-content of soil resulted lower arylsulphatase activity. The observed negative correlations between arylsulphatase activity and inorganic sulphate sulphur in soil was observed also by Gupta et al. (1988). The decline in arylsulphatase activity could also be attributed to the decrease in its source along with the end product inhibition caused by the higher $\mathrm{SO}_{4}-\mathrm{S}$ concentration in soil (Wainwright, 1980).

\section{CONCLUSIONS}

The amount of $\mathrm{KCl}$ and $\mathrm{CaCl}_{2}$ soluble sulphate of calcareous chernozem soil was approximately equal and varied between $0.3-2.2 \mathrm{mg} \mathrm{kg}$. Based on Pearson's correlation analysis, moderate correlation was observed between values of $1 \mathrm{M} \mathrm{KCl}$ soluble sulphate and the $0.01 \mathrm{M} \mathrm{CaCl}_{2}$ soluble sulphate $(\mathrm{r}=0.511)$.

The $\mathrm{KH}_{2} \mathrm{PO}_{4}$ soluble sulphate was the highest and ranged between $5.1-10.2 \mathrm{mg} \mathrm{kg} \mathrm{kg}^{-1}$. The adsorbed sulphate was calculated with the difference of values of $\mathrm{KH}_{2} \mathrm{PO}_{4}-\mathrm{SO}_{4}$ and values of $\mathrm{CaCl}_{2}-\mathrm{SO}_{4}$.
The adsorbed sulphate content of soil was typically higher at the highest fertilizer dose treatment compared to the control treatment and in the adsorbed sulphate contetn a slightly increment was observed in time.

Based on our results it can be concluded that the effect of sulphur present in superphosphate is nowadays still measurable. In most cases, the increasing fertilizer doses resulted higher sulphate content of soil compared to the control treatment.

It was confirmed by our measurements that the arylsulfatase enzyme activity was decreased with increasing sulphate content of the soil. The arylsulfatase activity of calcareous chernozem soil ranged between 9.284-26.860 $\mu \mathrm{g}$ p-nitrophenol $\mathrm{g}^{-1} \mathrm{~h}^{-1}$.

It is important to mention that the content of studied sulphur fractions in the soil was influenced by the local climatic conditions as well.

\section{ACKNOWLEDGEMENTS}

The publication was supported by the EFOP-3.6.3VEKOP-16- 2017-00008 project. The project is cofinanced by the European Union and the European Social Fund. 


\section{REFERENCES}

Eriksen, J. (2005): Gross sulphur mineralisation-immobilisation turnover in soil amended with plant residues. Soil Biology and Biochemistry, 37: 2216-2224.

Eriksen, J.-Thorup-Kristensen, K.-Askegaard, M. (2004): Plant availability of catch crop sulfur following spring incorporation. Journal of Plant Nutrition and Soil Science, 167: 609-615.

Fitzgerald, J. W. (1976): Sulfate ester formation and hydrolysis: a potentially important and often ignored aspect on the sulphur cycles of aerobic soils. Bacteriol. Rev., 40: 698-721.

Förster, S.-Welp, G.-Scherer, H. W. (2012): Sulfur specification in bulk soil as influenced by long-term application of mineral and organic fertilizers. Plant, Soil and Environment, 58: 316-321.

Gupta, V. V. S. R.-Lawrence, J. R.-Germida, J. J. (1988): Impact of elemental sulfur fertilization on agricultural soils. I. Effects on microbial biomass and enzyme activities, Can. J. Soil Sci. 68: 463-473.

Hu, Z. Y.-Zhao, F. F.-McGrath, S. P. (2005): Sulphur fractionation in calcareous soils and bioavailability to plants, Plant and Soil, 268: 103-109.

Johnson, D. W.-Henderson, G. S.-Todd, D. E. (1981): Evidence of modem accumulations of adsorbed sulfate in an east Tennessee forested ultisol. Soil Sci., 132, 422-426.

Kulhánek, M.-Balík, J.-Černý, J.-Sedlář, O.-Vašák, F. (2016): Evaluating of soil sulphur forms changes under different fertilizing systems during long-term field experiments, Plant Soil Environ., Vol. 62, 2016, No. 9: 408-415.
Net1: https://www.met.hu/eghajlat/magyarorszag_eghajlata/ eghajlati_visszatekinto/elmult_honapok_idojarasa/

Pirela, H. J.-Tabatabai, M. A. (1988): Reduction of organic sulfur in soils with tin and phosphoric acid. Soil Sci. Soc. Am. J., 52, 959-964.

Scherer, H. W. (2001): Sulphur in crop production - Invited paper. European Journal of Agronomy, 14: 81-111.

Scherer, H. W. (2009): Sulfur in soils. Journal of Plant Nutrition and Soil Science, 172: 326-335

Tabatabai, M. A. (1994): Soil enzymes In: Weaver RW et al Editors, Methods of soil analysis, part 2, Microbiological \&Biochemical properties 775-833.

Tabatabai, M. A.-Bremner, J. M. (1970a): Arylsulfatase activity of soils. Soil Sci Soc Am Proc 34:225-229.

Wainwright, M. (1980): Effect of eyprosure to athmospheric pollution on microbial activity in soil, Plant Soil. 55: 199-205.

Zhao, F.-McGrath, S. P. (1994): Extractable sulphate and organic sulphur in soils and their availability to plants. Plant Soil 164, 243-250. 